\title{
ACTUAL PROBLEMS OF PAYMENT OF CUSTOMS DUTIES
}

\author{
(C) 2020 Malyakova Alexandra Alexandrovna \\ Student \\ Samara State University of Economics \\ E-mail: sasha.malyakova@yandex.ru
}

Keywords: customs tariff regulation, customs duties, foreign economic activity, customs policy, customs business.

This article highlights the issues of customs payments, as well as their essence and role in the activities of customs authorities. The analysis of the dynamics of their receipt in the budget of the Russian Federation, as well as problematic aspects of levying customs duties and the most promising solutions to these problems.

УДК 342

Код РИНЦ 10.15 .00

\section{ВОЛОНТЕРСТВО В САМАРСКОЙ ОБЛАСТИ: АКТУАЛЬНЫЕ ВОПРОСЫ}

\author{
(c) 2020 Махмудов Магамед Салавудинович \\ студент \\ Самарский государственный экономический университет \\ E-mail: magamed660@mail.ru
}

\begin{abstract}
Ключевые слова: добровольчество, волонтеры, волонтерский центр, движение, гражданская активность.

Статья посвящена исследованию основ добровольческой деятельности на территории Самарской области. Приведены темы, остро касающиеся нашего региона в сфере добровольчества, а также характеристика и методы решения возникших вопросов по данной тематике.
\end{abstract}

Добровольчество - одно из самых распространенных движений в стране. Более 15 миллионов волонтеров участвуют в общественной жизни страны, помогают гражданам наших регионов, обеспечивают крепкую взаимосвязь с общественностью и придерживают высокую гражданскую активность.

Первое упоминание добровольчества в истории России было еще при правлении Екатерины II в конце 18 века была создана сеть воспитательных домов для детей-сирот и незаконнорожденных младенцев, в которых работали добровольцы. В дальнейшем широкое распространение получили благотворительные организации, фонды, которые также осуществляли волонтерскую деятельность на безвозмездной основе.

На территории Самарской области зафиксировано более 150 тысяч активных добровольцев, которые принимают активное участие в помощи организаций культурно-массовых мероприятий на территории региона, помогают людям на безвозмездной основе. 
Статистика роста численности добровольцев в год по сравнению с общей численностью населения. ${ }^{1}$

Таблица 1

\begin{tabular}{|c|l|c|c|c|}
\hline $\begin{array}{c}\text { № } \\
\text { п/п }\end{array}$ & $\begin{array}{c}\text { Федеральный } \\
\text { округ }\end{array}$ & $\begin{array}{c}\text { Численность } \\
\text { населения } \\
\text { (в среднем за год), } \\
\text { человек }\end{array}$ & $\begin{array}{c}\text { Численность } \\
\text { добровольцев } \\
\text { (в среднем за год), } \\
\text { человек }\end{array}$ & $\begin{array}{c}\text { Численность } \\
\text { добровольцев } \\
\text { в расчете на 1000 че- } \\
\text { ловек населения }\end{array}$ \\
\hline 1 & Центральный & 39260498 & 1187473 & 30,2 \\
\hline 2 & Приволжский & 29589635 & 357266 & 12,1 \\
\hline 3 & Сибирский & 19306835 & 357115 & 18,5 \\
\hline
\end{tabular}

Добровольческое движение получило активное распространения именно в 2018 году с проведением ЧМ-2018 по футболу. Город Самара был удостоен чести принять участие в помощи проведения и организации данного события, более 3-х тысяч волонтеров приняли участие в данном событии на территории региона.

Волонтеры принимают участие в мероприятиях городского, всероссийского и мирового масштаба, выполняя самые разнообразные функции от координации гостей до участия в шоу-постановках.

В добровольческой деятельности Самарской области активное развитие волонтерского движения несет за собой проблему низкого уровня про информированности и подготовки добровольцев, связанный с огромной притоком активных ребят к данной деятельности и малой доступности центров по обучение добровольческой деятельности².

В Самарской области актуальными вопросами в сфере добровольчества стало касаться основа творческого, культурного воспитания региона, прививание патриотизма по отношению к истории нашей области, развития правовой грамотности населения и не только.

Каждый вопросы по-своему уникальны и несут за собой определенный порядок последовательных действий.

Таблица 2

\begin{tabular}{|c|l|c|c|c|}
\hline $\begin{array}{c}\text { № } \\
\text { п/п }\end{array}$ & $\begin{array}{c}\text { Федеральный } \\
\text { округ }\end{array}$ & $\begin{array}{c}\text { Численность насе- } \\
\text { ления } \\
\text { (в среднем за год), } \\
\text { человек }\end{array}$ & $\begin{array}{c}\text { Численность } \\
\text { добровольцев } \\
\text { (в среднем за год), } \\
\text { человек }\end{array}$ & $\begin{array}{c}\text { Численность } \\
\text { добровольцев } \\
\text { в расчете на 1000 че- } \\
\text { ловек населения }\end{array}$ \\
\hline 4 & Южный & 16435155 & 251491 & 15,3 \\
\hline 5 & Северо-Западный & 13925656 & 162879 & 11,7 \\
\hline 6 & Уральский & 12351016 & 137041 & 11,1 \\
\hline 7 & Северо-Кавказский & 9799625 & 176434 & 18,0 \\
\hline 8 & Дальневосточный & 6173982 & 101953 & 16,5 \\
\hline
\end{tabular}

Развитие творческого и культурного потенциала региона исходит с образованием на территории РФ региональных штабов волонтеров культуры. Основной задачей добровольцев в данной сфере является культурное просвещение о достоинствах и достоприме- 
чательностях региона, о его историческом прошлом в подробных особенностях для туристов и жителей Самарской области.

Подразумевается, что волонтеры применяют свои знания и навыки в библиотеках, театрах и домах культуры, а также на крупных городских событиях, как, например, "Ночь музеев" и "Библионочь", где добровольцы принимают участие с целью создания атмосферы открытости и привлечения новых посетителей. Они проводят лекции и мастер классы, помогают воспитателям с ограниченными возможностями здоровья, оказывают помощь в подготовке выставок и проведении научной работы.

В развитие патриотического воспитания и общей гражданской активности на территории области выступают различные общественные организации. Данный процесс является наиболее актуальным и востребованным на данным период времени и нуждается в наибольшем привлечении молодого поколения к его участию.

Наиболее распространенным в данном движении является организация "Волонтеры Победы". Основой их деятельности является поддержания патриотического духа на территории региона, восстановление, сохранении истории и исторических фррагментов прошедшего времени и помощь ветеранам BOB³.

Данный вопрос актуален, как никогда, так как держит в себе основу дальнейшего развития молодежи на территории регионов. В Самарской области данное движении имеет массовое распространение и люди с желанием активно участвуют в мероприятиях направленных на патриотическое воспитание молодежных активов.

Развитие правовой грамотности, как один из актуальных вопросов затронут не случайно. В своем характере данное направление несет в обучении и правовом просвещении граждан региона с правовой точки зрения в разных сферах жизни общества, как в сфере ЖКХ, так и до финансовой сферы.

Точно ли относится это к добровольческой деятельности, еще стоит под вопросов, но известно, уже давно, как одной из основной деятельностью юристов является оказание бесплатной юридической помощи, что не может говорить о ее добровольном характере в праве оказания помощи граждан на безвозмездной основе.

На основании федерального закона "О благотворительной деятельности и добровольчестве" прописано, что под добровольческой деятельностью понимается добровольная деятельность в форме безвозмездного выполнения работ и (или) оказания услуг в целях, как один из пунктов оказания бесплатной юридической помощи и правового просвещения населения 4 .

На территории Самарской области данное движение не имеет в своем роде широкого распространения, именно как волонтерское движение, так как нет компетентных волонтеров для данного рода деятельности. В данном случае каждый должен пройти обучающие курсы, которые покажут уровень подготовки прошедших обучение для вынесения информации в массы общества.

Основная проблема заключается в малой обеспеченности обучающих курсов для ново пришедших добровольцев. Большая часть не обладает и большим количеством компетентных навыков для ведения и помощи на определенных функциях и обучаются в процессе их выполнения, что сказывается на качестве и исполнительности данной задачи.

Истоком всего исходит массовые потоки желающих участвовать в волонтерской деятельности. Данное явление приносит как свои плюсы, так и минусы ${ }^{5}$. 
Плюсы. Большое количество волонтеров дает возможность организации на территории региона крупных культурно-массовых мероприятий с их участием. Следующее, увеличении количества направлений добровольчества в Самарской области. Каждое движение организует новые явления, тем самым обогащая область в новом ветке развития.

Минусы. Низкий уровень подготовки и качества исполнения деятельности волонтеров. Из-за массовых притоков добровольцев организация добровольческих курсов имеет определенные сложности, тем самым большинство волонтеров не имеют понятия о части роли исполнения в деятельности в процессе организации мероприятий.

Не смотря на данные плюсы и минусы в сфере добровольческого движения Самарский регион, а именно Муниципальное бюджетное учреждение городского округа Самара "Самарский Дом молодежи" - занял 3 место в номинации "Волонтерский центр", что говорит об уровне организации и подготовки добровольцев данной организации на территории городского округа.

Рассматривая актуальные вопросы волонтерства в Самарской области, то можно выделить следующие факторы, определяющие общее положение региона в данной деятельности:

- Развитие творческого и культурного потенциала региона исходит с образованием на территории РФ региональных штабов волонтеров культуры

- В развитие патриотического воспитания и общей гражданской активности на территории области выступают различные общественные организации.

- Развитие правовой грамотности в своем характере данное направление несет в обучении и правовом просвещении граждан региона с правовой точки зрения в разных сферах жизни общества, как в сфере ЖКХ, так и до финансовой сфреры.

В итоге для решения данной проблемы, необходимо расширить базис добровольческий организаций в сфере подготовки волонтеров к добровольческой деятельности, на основании предоставления доступных муниципальных, городских ресурсов для развития и расширения подготовительных центров на базе добровольчества.

Так или иначе, именно добровольческое движение помогает региону развивать молодое поколение и давать перспективы его в дальнейшее развитие.

1 Доклад "О проведении научных, социологических и статистических исследований, направленных на изучение форм и масштабов участия граждан и организаций в добровольческой (волонтерской) деятельности".

URL: https://ac.gov.ru/archive/files/publication/a/21338.pdf (дата обращения 10.03.2020).

2 Bolgova V.V., Cherevichenko T.S., Azarkhin A.V., Sidorova A.V., Efremova E.A. INTERNET OFFENSES OF YOUNG POPULATION //

В сборнике: Lecture Notes in Networks and Systems Growth Poles of the Global Economy: Emergence, Changes and Future Perspectives. Plekhanov Russian University of Economics. Luxembourg, 2020. C. $667-675$.

${ }^{3}$ Климова С. Г. Идеи и практики солидарности в добровольческом движении, Социс, 6, 32-41

4 Федеральный закон от 5 февраля 2018 г. N 15-Ф3 "О внесении изменений в отдельные законодательные акты Российской Федерации по вопросам добровольчества (волонтерства)". URL: https://rg.ru/2018/02/07/volonteri-dok.html (дата обращения 10.03.2020). 
5 Шапка Е. Н. Волонтерство сегодня: модный тренд или полноценная работа? 6-й конкурс эссе ЦИГЕ и Когитару (2013) http://www.cogita.ru /grazhdanskayaaktivnost/volonterstvo/6-i-konkurs-essevolonterstvo-idobrovolchestvo-v-evrope-i-rossii/volonterstvo-segodnyamodnyi-trend-ili-polnocennayarabota (дата обращения 10.03.2020).

\title{
VOLUNTEERING IN THE SAMARA REGION: ACTUAL ISSUES
}

(C) 2020 Mahmudov Magamed Salavudinovich

Student

Samara State University of Economics

E-mail: magamed660@mail.ru

Keywords: Volunteering, volunteers, volunteer center, movement, civic activism.

The article is devoted to the survey of the basics of volunteering in the Samara region. The topics are acutely related to our region in the field of volunteering, as well as characteristics and methods for resolving issues arising on this topic.

УДК 343

Код РИНЦ 10.00.00

\section{НЕКОТОРЫЕ ВОПРОСЫ УГОЛОВНОЙ ОТВЕТСТВЕННОСТИ ЗА ИЗГОТОВЛЕНИЕ И СБЫТ ПОДДЕЛЬНЫХ ДЕНЕЖНЫХ СРЕДСТВ ИЛИ ЦЕННЫХ БУМАГ}

\author{
(C) 2020 Милова Ирина Евгеньевна \\ кандидат юридических наук, доцент \\ (C) 2020 Азарова Виктория Владимировна \\ студент \\ () 2020 Левкина Елизавета Алексеевна \\ студент
}

Самарский государственный экономический университет

E-mail: irina.milova@ro.ru, v1kazarova1410@mail.ru, rudinaagata@gmail.com

Ключевые слова: преступление, денежные средства, ценные бумаги, фальшивомонетничество, фальсификация, экономика, поддельные купюры, поддельные денежные знаки, предупреждение фальшивомонетничества, экономическая безопасность.

Необходимыми элементами регулирования экономических отношений в Российской Федерации являются денежные средства и ценные бумаги. С развитием рыночных механизмов в нашей стране, в качестве побочного проявления, развивается фальшивомонетничество и фальсификация ценных бумаг, что, безусловно, оказывает негативное влияние и даже ставит под угрозу экономическое положение государства не только на национальном уровне, но и на международной арене. 